Journal of Animal and Veterinary Advances 9 (11): 1617-1620, 2010

ISSN: $1680-5593$

(C) Medwell Journals, 2010

\title{
Molecular Cloning and Polymorphism Analysis on Exon 2 of Thyroid Hormone Responsive Spot 14 Gene in Geese
}

\author{
Na Qiao, Rong-Xue Zhao, Xue-Bin Wang, Qi Xu, Jin-Hua Cheng, \\ Wen-Ming Zhao and Guo-Hong Chen \\ College of Animal Science and Technology, Yangzhou University, \\ Yangzhou 225009, China
}

\begin{abstract}
This experiment was conducted to study the Polymorphism on exon 2 of THRSP $\alpha$ gene in goose. The Single Nucleotide Polymorphism (SNP) of (Thyroid Hormone Responsive Spot 14 gene) THRSP $\alpha$ gene was investigated in Zi geese, Wanxi White geese, Zhedong White geese and Shitou geese. One primer for exon 2 of THRSP $\alpha$ gene were designed according to the homologous sequence of duck. Six SNPs were found in the sequence of THRSP $\alpha$ gene and 6 genotypes $\mathrm{AA}, \mathrm{BB}, \mathrm{CC}, \mathrm{AB}, \mathrm{AC}$ and $\mathrm{BC}$ were detected in 4 goose populations. All the populations were in Hardy-Weinberg equilibrium at this polymorphic site ( $p>0.05)$. The results confirmed that there were polymorphisms in the exon 2 of THRSP $\alpha$ gene.
\end{abstract}

Key words: Goose, Thyroid Hormone Responsive Spot 14 (THRSP $\alpha$ ) gene, Single Nucleotide Polymorphism (SNP), polymorphism, genetic variation, China

\section{INTRODUCTION}

The Thyroid Hormone Responsive Spot 14(THRSP $\alpha$ ) gene also known as Spot 14 began nearly 3 decades ago. Investigators used two dimensional gel electrophoresis of in vitro translated products to survey the effect of thyroid hormone on rat hepatic gene expression (Seelig et al., 1981). It encodes a small acidic protein expressed predominately in the adipogenic tissues such as the lactating mammary gland, fat and the liver (Jump et al., 1984; Jump and Oppenheimer, 1985). Among the transcripts that responded to both thyroid hormone and a lipogenic (high carbohydrate) diet was the mRNA for Spot 14 so named because it was the 14th spot on the gel noted to change in response to thyroid hormone status.

The chicken THRSP gene was found in livers of chickens divergently selected for fast or slow growth rates. It was cloned by in silico EST assembling and was identified to duplicate into 2 paralogs, THRSP $\alpha$ and THRSP $\beta$ (Wang et al., 2004). Sequence analysis of mammal and chicken THRSP genes demonstrated that both of them shared a similar gene organization with 2 exons and an intron (Grillasca et al., 1997; Wang et al., 2004). Duck THRSP $\alpha$ and THRSP $\beta$ were predicted to encode peptides with 133 amino acids. A high percentage (73.1\%) of $\mathrm{G}$ and $\mathrm{C}$ nucleotides were found in the $3^{\prime}$ untranslated region of duck THRSP $\beta$ cDNA (Zhan et al., 2006). Geese and ducks belong to waterfowl and both of them share de novo fatty acid biosynthesis mainly in the liver. THRSP gene may play an important role in avian adipogenesis and it is necessary to get DNA sequence of goose THRSP gene for future functional genomic investigations. In this study, the sequence of goose $\operatorname{THRSP} \alpha$ gene was amplified and the single nucleotide polymorphisms were analyzed in four Chinese indigenous goose populations. The results may help to understand the genetic effect of THRSP $\alpha$ gene on goose productive traits.

\section{MATERIALS AND METHODS}

Goose populations: Four Chinese indigenous goose populations including $59 \mathrm{Zi}$ geese from Jilin, 66 Wanxi white geese from breeding station in Anhui Province, 71 Zhedong white geese provided by National Waterfowl Germplasm Resource Pool in Jiangsu province, 67 Shitou geese from breeding station in Guangdong province, China. The total number of samples were 263 individuals, all the individuals were raised under the same standard condition.

Primers design: One pairs of primer were designed according to the DNA sequence of duck THRSP $\alpha$ gene (Genbank NO: DQ334339). This primer was used to amplify exon 2 of goose THRSP $\alpha$ gene (Table 1 ).

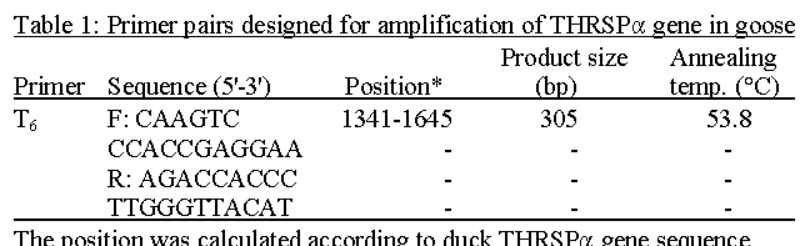

Corresponding Author: Guo-Hong Chen, Animal Science and Technology, Yangzhou University, Yangzhou 225009, China 
SNPs identification with PCR-SSCP technique and sequencing confirmation: Goose genomic DNA was extracted from blood sample and diluted to $100 \mathrm{ng} \mu \mathrm{L}^{-1}$. PCR was performed in $20 \mu \mathrm{L}$ mixture containing $100 \mathrm{ng}$ of goose genomic DNA, $10 \times \mathrm{PCR}$ buffer $\left(\mathrm{Mg}^{2+}\right.$ free $) 2 \mu \mathrm{L}$, $25 \mathrm{mmol} \mathrm{L}^{-1} \mathrm{MgCl}_{2} 1 \mu \mathrm{L}, 2.5 \mathrm{mmol} \mathrm{L}^{-1}$ of each dNTP $1 \mu \mathrm{L}$, $10 \mu \mathrm{mol} \mathrm{L}{ }^{-1}$ primers $1 \mu \mathrm{L}, 0.2 \mu \mathrm{L}(1.0 \mathrm{U})$ Taq DNA polymerase (TakaRa Biotechnology Dalian Co., Ltd.), $100 \mathrm{ng} \mu \mathrm{L}$ genomic DNA $1 \mu \mathrm{L}$ and $12.8 \mu \mathrm{L} \mathrm{ddH}_{2} \mathrm{O}$.

PCR was run with the following procedure: $95^{\circ} \mathrm{C}$ for $5 \mathrm{~min}$ followed by $35 \mathrm{cycles}$ of $50 \mathrm{sec}$ at $94^{\circ} \mathrm{C}, 50 \mathrm{sec}$ at annealing temperature $53.8^{\circ} \mathrm{C}, 50 \mathrm{sec}$ at $72^{\circ} \mathrm{C}$ and a final extension of $10 \mathrm{~min}$ at $72^{\circ} \mathrm{C}$.

Genotypes of all the primers were observed by PCR-SSCP procedure as follows: $10 \mu \mathrm{L}$ PCR product was mixed with $5 \mu \mathrm{L}$ loading buffer, heating at $98^{\circ} \mathrm{C}$ for $10 \mathrm{~min}$, then bathing in ice for $5 \mathrm{~min}$ and visualizing with $10 \%$ polyacryamide gel electrophoresis.

The PCR fragments were purified with a DNA fragment purification kit (TakaRa Biotechnology Dalian Co., Ltd.), then cloned and sequenced in the company (Sangon Biological Engineering Technology Company, Shanghai, China).

Statistical analysis: Chi-squares analysis was done by Chi-square calculator V1.51; the sequences alignment was carried out by DNA star and Align IR 2.0 software.

\section{RESULTS AND DISCUSSION}

The sequence confirmation of goose THRSP $\alpha$ gene exon 2 fragment: Three individuals of each genotype were selected randomly to clone and sequence. The results were shown in Fig. 1.
The identity of sequences amplified between goose and duck was $89.00 \%$.

The genetic variation of goose THRSP $\alpha$ gene exon 2 fragment: About 6 SNPs were detected by this primer. The mutations were G19A, C62T, G70C, A136G, A198G and G244A, respectively (Fig. 2) (the number was calculated from the first base of amplified fragment by the primer).

Six genotypes $\mathrm{AA}, \mathrm{BB}, \mathrm{CC}, \mathrm{AB}, \mathrm{AC}$ and $\mathrm{BC}$ were generated among 4 populations (Fig. 3), the genotypes distribution and gene frequency of the polymorphic primer in 4 populations were shown in Table 2.

Two exons in goose THRSP $\alpha$ gene were amplified according to duck THRSP $\alpha$ gene sequences. The results suggested that the sequence of THRSP $\alpha$ gene exon 2 was highly conserved between goose and duck. The role of $\operatorname{THRSP} \alpha$ gene at fat induced generation have been studied extensively. Compe et al. (2001) report that the amount of the Spot 14 protein is closely related to the full expression of enzymes involved in the glycolytic and lipogenic pathways. In mammals, THRSP is a small acidic protein that is predominately expressed in lipogenic tissue (i.e., liver, abdominal fat and the mammary gland).

This gene has been postulated to play a role in lipogenesis, since it responds to thyroid hormone stimulation, high glucose levels and it is localized to a chromosomal region implicated in obesity. Wang et al. (2004) report that the THRSP $\alpha$ locus is associated with abdominal fat traits in resource population.

The polymorphic alleles involving a variable number of tandem repeats were discovered in the putative protein

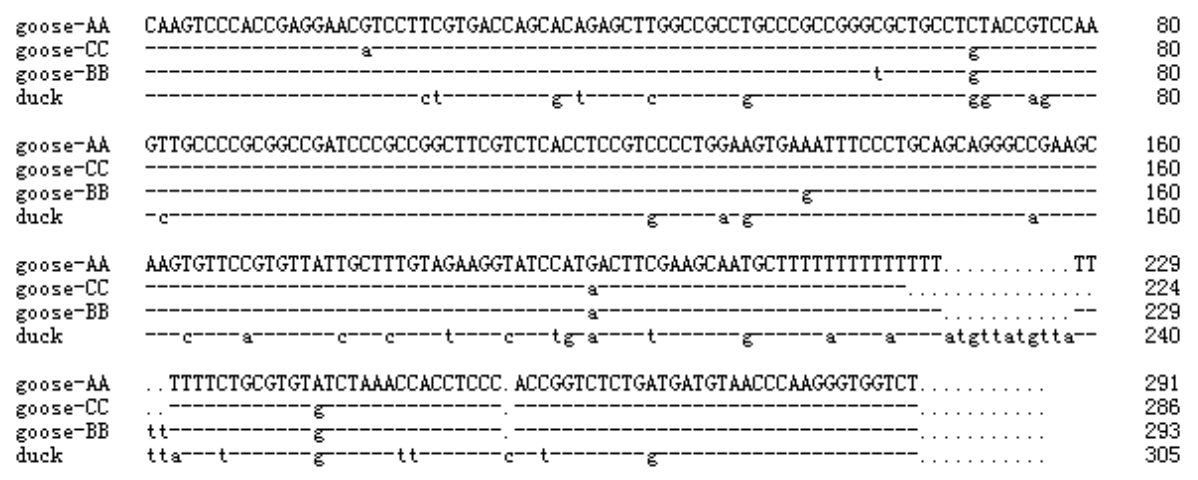

Fig. 1: The sequences of goose THRSP $\alpha$ gene exons fragment and the alignment with duck, means the identical base; goose-AA, goose-BB and goose-CC represent different homozygotes 


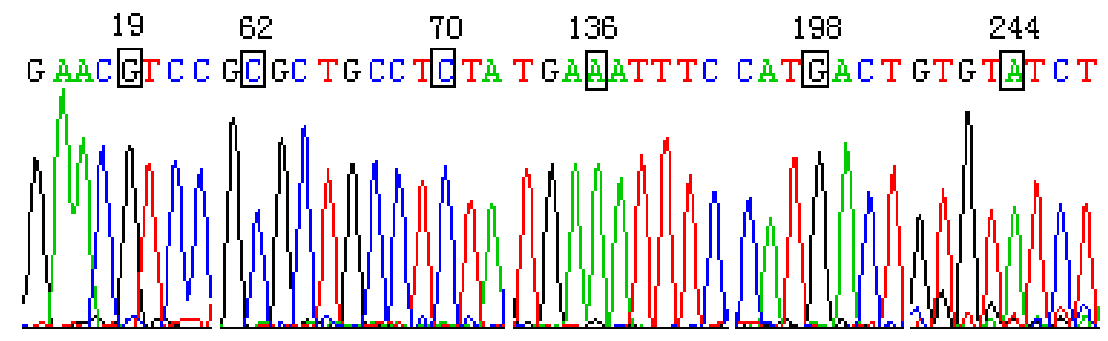

Ah genotype

19

62

70

136

198

244

G A

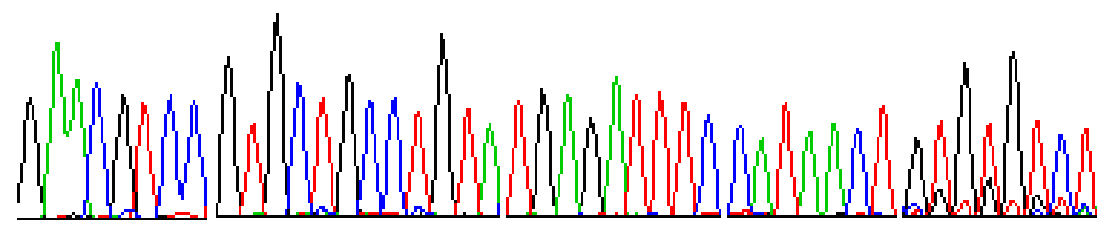

$\mathrm{BB}$ genotype

$\begin{array}{llllll}19 & 62 & 70 & 136 & 198 & 244\end{array}$

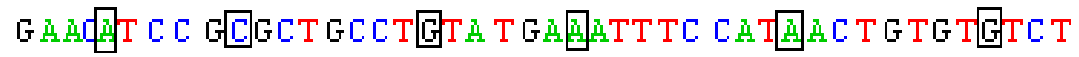

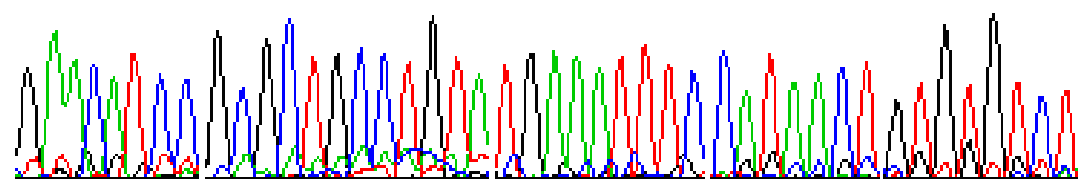

CC genotype

Fig. 2: Chromatograms showing sequence variations at each position within the sequence of THRSP $\alpha$ gene exon 2, bases in frame were the mutation positions

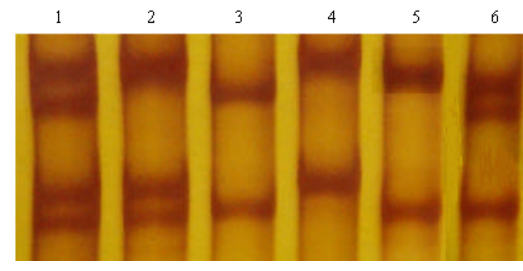

Fig. 3: Different genotypes visualized by electrophoresis. 5 , AA genotype; 4, BB genotype; 3, CC genotype; $2, \mathrm{AB}$ genotype; $1, \mathrm{BC}$ genotype $6, \mathrm{AC}$ genotype

coding region of the duplicated chicken THRSP $\alpha(9 \mathrm{bp})$ and THRSP $\beta$ ( 6 or 12 bp) genes. Zhan et al. (2007) cloned the full length of THRSP $\alpha$ gene of ducks and was used to detect the polymorphism in THRSP $\alpha$ intron. The association of mutation locus with growth and body compositions of 238 Pekin ducks was investigated by PCR-RFLP method and the C239A in THRSP $\alpha$ intronwas cut by enzyme Sac I. In the study, 6 SNPs were detected with the method of PCR-SSCP and sequencing. Considering the essential effects of THRSP $\alpha$ gene on animal traits that previous studies have proved, it can be presumed that the mutations detected in this study may affect some production traits of goose. Zi goose is a small egg-type goose and Wanxi white goose, Zhedong white goose are medium dual type goose.

Shitou goose was the largest meat-type goose. The proportion of AA genotype was dominant in all 4 Chinese indigenous geese and $\mathrm{AB}$ genotype was second dominant. Frequency of $\mathrm{B}$ allele more than $\mathrm{C}$ allele in $\mathrm{Zi}$ goose, Wanxi white goose and Zhedong white goose which was significantly different from Shitou goose.

This result suggested that goose THRSP $\alpha$ gene may affect the traits of different populations in different ways. And further studies should be conducted in the relationships of THRSP $\alpha$ gene polymorphism and carcass traits in Goose. 
Table 2: Sample size, genotype and gene frequency in 4 goose populations for the polymorphic primer pairs

\begin{tabular}{|c|c|c|c|c|c|c|c|c|c|c|c|}
\hline \multirow[b]{2}{*}{ Population } & \multirow{2}{*}{$\begin{array}{c}\text { Sample } \\
\text { size }\end{array}$} & \multicolumn{6}{|c|}{ Genotype frequency } & \multicolumn{3}{|c|}{ Allele frequency } & \multirow[b]{2}{*}{$\chi^{2}$} \\
\hline & & $\mathrm{AA}$ & $\mathrm{BB}$ & $\mathrm{CC}$ & $\mathrm{AB}$ & $\mathrm{AC}$ & $\mathrm{BC}$ & $\mathrm{A}$ & $\mathrm{B}$ & $\mathrm{C}$ & \\
\hline $\mathrm{Zi} \mathrm{goose}$ & 59 & $39(0.661)$ & $1(0.017)$ & $1(0.017)$ & $12(0.203)$ & $6(0.102)$ & $0(0.000)$ & 0.813 & 0.119 & 0.068 & $2.12^{\mathrm{ns}}$ \\
\hline Wanxi white goose & 66 & $29(0.439)$ & $9(0.136)$ & $3(0.046)$ & $20(0.303)$ & $4(0.061)$ & $1(0.015)$ & 0.621 & 0.296 & 0.083 & $6.07^{\mathrm{ns}}$ \\
\hline Zhedong white goose & 71 & $53(0.746)$ & $3(0.042)$ & $2(0.028)$ & $7(0.099)$ & $6(0.085)$ & $0(0.000)$ & 0.838 & 0.092 & 0.070 & $5.26^{\text {ns }}$ \\
\hline Shitou goose & 67 & $44(0.657)$ & $0(0.000)$ & $4(0.060)$ & $4(0.060)$ & $14(0.208)$ & $1(0.015)$ & 0.791 & 0.037 & 0.172 & $1.21^{1 \mathrm{~ns}}$ \\
\hline
\end{tabular}

$\chi^{2}$ values means the test values of different genotype to Hardy-Weinberg balance; Means with ns in column are not significantly different $(\mathrm{p}>0.05)$

\section{CONCLUSION}

This experiment was conducted to study the Polymorphism on exon 2 of $\operatorname{THRSP} \alpha$ gene in goose. Six SNPs were found in the sequence of THRSP $\alpha$ gene and 6 genotypes were detected in 4 goose populations. All the populations were in Hardy-Weinberg equilibrium at this polymorphic site $(\mathrm{p}>0.05)$. The results confirmed that there were polymorphisms in the exon 2 of THRSP $\alpha$ gene.

\section{ACKNOWLEDGEMENTS}

This study was supported by Mordern Agricultural Industry Technology System Special Fund (nycytx-45-04), National Science and Technology Planning Project (2006BDA01A09 and 2006BDA14B06) and Provincial Universities Natural Science Basic Research Project (07KJB230138) in Jiangsu, China.

\section{REFERENCES}

Compe, E., G. de Sousa, K. Francois, R. Roche and R. Rahmani et al., 2001. Spot 14 protein interacts and co-operates with chicken ovalbumin upstream promoter transcription factor 1 in the transcription of the L-type pyruvate kinase gene through a specificity protein 1 (Spl) binding site. Biochem. J., 358: 175-183.
Grillasca, J.P., M. Gastaldi, H. Khiri, A. Dace and N. Peyrol et al., 1997. Cloning and initial characterization of human and mouse Spot 14 genes. FEBS Lett., 401: 38-42.

Jump, D.B. and J.H. Oppenheimer, 1985. High basal expression and 3,5,3'-triiodothyronine regulation of messenger ribonucleic acid S14 in adipogenic tissues. Endocrinology, 117: 2259-2266.

Jump, D.B., P. Narayan, H. Towle and J.H. Oppenheimer, 1984. Rapid effects of triiodothyronine on hepatic gene expression. J. Biol. Chem., 259: 2789-2797.

Seelig, S., C. LIuw, H.C. Towle and J.H. Oppenheimer, 1981. Thyroid hormone attenuates and augments hepatic gene expression at a pretranslational level. Proc. Natl. Acad. Sci. USA., 78: 4733-4737.

Wang, X., W. Carre, H. Zhou, S.J. Lamont and L.A. Cogburn, 2004. Duplicated Spot 14 genes in the chicken: Characterization and identification of polymorphisms associated with abdominal fat traits. Genetics, 332: 79-88.

Zhan, K., G.Y. Xu and N. Yang, 2007. Comparative genomic analysis of thyroid hormone responsive spot14 alpha gene ( THRSP $\alpha$ ) in ducks Acta Vet. Zootech. Sinica, 38: 521-525.

Zhan, K., Z.C. Hou, H.F. Li, G.Y. Xu, R. Zhao and N. Yang, 2006. Molecular cloning and expression of the duplicated thyroid hormone responsive spot 14 (THRSP) genes in ducks. Poult. Sci., 85: 1746-1754. 